\title{
Yunus Emre ve Derviş Olmak
}

\section{A Dervish in Yunus Emre's Conception}

\author{
Mehmet Necmeddin Bardakçı*
}

Öz

Tasavvuf, i̇slâmiyet'in ahlâk anlayışını yaşatmaya çalışan, nazariyeden çok amele önem veren bir disiplindir. Tasavvufun şahsiyet eğitiminde ahlâkî değerlerin önemi büyüktür. Hz. Peygamber'in güzel ahlâkını yaşamayı ülkü edinen sûfiler, riya, haset, kibir ve kendini beğenme gibi kötü hasletleri terk ederek sıdk, ihlâs, sabır, şükür ve kanaat gibi güzel erdemleri kazanırlar. Çünkü tasavvuf, bireyleri güzel ahlâkla terbiye edip toplumda erdemlerin yaşanmasını gaye edinmiştir. Zira ahlâkî değerler yaşandıkları zaman anlamlı olur.

Horasan'ın melâmet, cezbe ve aşk anlayışları ile Türkistan'ın pratik ahlâk odaklı tasavvuf anlayışını terkip eden Yunus Emre de ahlâkî erdemlerin yaşatılmasına önem vermiştir. Şiirlerinde aşk, insan-ı kâmil, hayat-ölüm, varlık-yokluk gibi metafizik konuları ilâhî aşk ve ahlâk temeline oturtarak anlatmıştrr. Sevgi ve hoşgörü sembolü olan Yunus Emre'nin düşüncesindeki derviş, Allah'ı seven âşık, zâhid ve sûfî gibi terimlerle eşanlamlıdır. Derviş olmak; benlik sevdasından vaz geçip alçakgönüllü ve fedakâr olmak, hiç kimseyi küçük görmemek ve incitmemektir. Derviş; iyilik yapan, bir tebessümle gönül alan, bir canı yaşatmayı bütün canları yaşatmak gibi görüp insanlığa sahip çıkandır. Nefsi terbiye yöntemi olan dervişlik; kalpten kötülükleri silip iyilikleri yerleştirmek suretiyle yeni bir benlik inşa sürecidir. Gerçek derviş, her gün aynanın karşısına geçip nefis muhasebesi yaparak ölmeden önce ölme şuurunu yakalayandır.

\section{Anahtar Kelimeler}

Yunus Emre, derviş, aşk, edep, ahlâk, tevazu

\section{Abstract}

Sufism aims to perpetuate social values by inculcating high moral standards in individuals. The character education of Sufism accords great importance to moral values. Sufis adopt the ideal of living according to the Prophet's principles of excellence. They abandon negative traits, such as hypocrisy, envy, and arrogance, and build virtues, such as sincerity, patience, gratitude, and contentment. Ethical practices are precious; thus, Sufism instructs individuals to imbibe good morals and experience social virtues.

Yunus Emre combined Khorasan's comprehension of reproach, ecstasy, and love with the practical and ethics-oriented Sufi understanding of Turkestan. He also emphasized the preservation of moral virtues. His poetry describes metaphysical issues such as love, human perfection, life-death, and existence-nonexistence based on divine love and morality. Yunus Emre symbolizes love and tolerance and defines the dervish as a lover of God, renunciant, and Sufi. To be a dervish is to relinquish self-love, embody humility and self-sacrifice, and not belittle or hurt anyone. A dervish is someone who acts in kindness, makes others happy with a smile, and protects humanity by recognizing that "to keep one life alive is to keep all lives alive." Being a dervish represents a method of self-discipline; it denotes the process of constructing a new self by removing evil from the heart and replacing it with virtue. A true dervish practices daily self-reflection and thus realizes death before dying.

\section{Keywords}

Yunus Emre, dervish, love, decency, moral, modesty

* Sorumlu Yazar: Mehmet Necmeddin Bardakçı (Prof. Dr.), Süleyman Demirel Üniversitesi, illahiyat Fakültesi, Temel İslam Bilimleri Bölümü, Isparta, Türkiye. E-posta: necmettinbardakci@sdu.edu.tr ORCID: 0000-0003-3903-6257

Atff: Bardakci, Necmeddin Mehmet. "Yunus Emre ve Derviş Olmak." darulfunun ilahiyat 32, 'Yunus Emre' Özel Sayısı (2021): $107-127$. https://doi.org/10.26650/di.2021.32.963319 


\section{Extended Summary}

\section{Introduction}

Sufism aims to immortalize social values by nurturing individuals who evince high moral standards. Numerous Sufis have thus defined Sufism as morality and decency. To be a dervish is to manifest the principles of the Qur'an embodied in the Prophet, to look at life through the lens of love and tolerance, to relinquish self-love, to be humble and altruistic, and not to hold anyone in disrespect or hurt anybody. A dervish attains the trust of both friends and enemies and does not cause any anxiety about his sense of fairness. A dervish protects humanity by recognizing that "to keep one life alive is to keep all lives alive" and also understands that "to kill someone is to set the world on fire." Yunus Emre owned all these qualities, and his poetry expressed the importance of being a virtuous person and a good Muslim.

\section{Yunus Emre Era}

Yunus Emre lived between the second half of the $13^{\text {th }}$ century and the first half of the $14^{\text {th }}$ century. The country was catapulted into if great depression at the time of his birth because of two events in Anatolia: the Babaîler Revolt in 1240 and the Kösedağ War between the Anatolian Seljuk State and the Mongols in 1243. These two events disrupted Anatolian unity and destroyed peace. Yunus Emre thus lived at a time of disintegrating accord and declining peace and stability in Anatolia. Conversely, at this time, Anatolia had become a place where the Sufi comprehension of Khorasan, Turkestan, Iraq, and Damascus blended with the Andalusian conception of Sufism. Numerous Sufis such as Evhaduddin Kirmani, Ibnu'lArabi, Necmeddin Dâye, Hacı Bektaş-1 Velî, Mevlana Celaleddin Rumi, and Sadreddin Konevî were active in Anatolia. The Sufi movements Anatolia witnessed in the $13^{\text {th }}$ century exhibited great diversity. These groups encompassed many Sunni and non-Sunni elements and may be classified into two groups: those operating in urban and rural areas.

Yunus Emre's Sufi teachings were shaped within the Yesevi and Rifai traditions. His sheikh, Tapduk Emre, obtained his authorization from Sinan Ata, a Turkish sheikh from Bukhara. Sinan Ata belonged to the Yesevi tradition and arrived in Anatolia during the Mongol invasion. Besides Sinan Ata, Tapduk Emre also attained his autorization from Sari Saltuk and Barak Baba. Mahmud Hayrani, the sheikh of Sari Saltuk, was authorized by the Rifai sect. Barak Baba was Sari Saltuk's disciple; hence, Yunus Emre was a dervish who belonged to Rifai and Yesevi sects.

\section{Yunus Emre and Dervishness}

Fundamentally, Sufism and dervishness is to value human beings and to love the created for the Creator's sake. The richness of the heart, generosity, getting along with people, being aware of the innermost phenomena, never rejecting truth, being sincere and honest, valuing every moment, and existing without worldly illusions also constitute attributes 
of a dervish. These qualities ensure that the dervish's words and deeds comply with the Sunnah of Prophet Muhammad (PBUH) and enable a dervish to ignore faults in people, forgive mistakes, and remain decent and moral. Dervishness is inappropriate for people whose words, behaviors, and attitudes do not comply with the Book and Sunnah. Yunus Emre chose the path of love, valued love above all else, and regarded it as a divine gift. The path of love and ecstasy is deemed in Sufism to be the shortest route to Allah; however, this path poses many dangers and difficulties. The mind guides people to a certain point on the path of love. The process, through which harmonic Sufi experiences, such as tawhî, fenâ, and cem, are encountered occurs through love and not reason. Yunus's understanding of love and tolerance was not limited to his own neighborhood or to Muslims; rather, it encompassed everyone. Therefore, his poetry recommended kindness, honesty, and cooperation for all Muslims without discriminating between sects and dispositions.

Yunus Emre combined Khorasan's understanding of reproach, ecstasy, and love with the human-oriented Sufism conception of Turkestan. He also emphasized the preservation of moral virtues. His poems described metaphysical issues such as love, human perfection, life-death, and existence-nonexistence based on divine love and morality. Yunus Emre symbolized love and tolerance and defined the dervish as a lover of God. A dervish has open eyes, a pure heart, and ears in love with the word of God and the Prophet. According to Yunus Emre, the identity of a dervish represents a method of selfdiscipline through worship, dhikr, evrad, and self-denial. The being of a dervish denotes the process of building a new self by removing evil from the heart and replacing it with virtue. The true dervish attains the consciousness of death before dying by practicing daily self-reflection. Being a dervish means sacrificing the self for the sake of friends, living without compromising righteousness and honesty, and being generous and good as a person. Only those with good hearts can become dervishes; dervishness cannot be achieved by wearing a patched cardigan or crown. Yunus Emre underscored that the identity of a dervish requires the internalization of qualities such as honesty, sincerity, justice, love, tolerance, self-sacrifice, and generosity. Dervishes set righteous examples for society through their conduct.

Yunus Emre stressed that negative emotions such as hypocrisy, envy, and arrogance represented major obstacles in the spiritual journey of a disciple. He cared about the struggles disciples experienced with their souls to achieve the stage of fenafillah. He asserted that the lives of disciples who accounted for their actions at the end of every day would be easily accountable on the day of judgment. However, he also stated that some disciples erred by ignoring this fact.

\section{Yunus Emre's Critique of Dervishness}

Yunus Emre highlighted the impossibility of God's love flowing into the hearts of people who forgot true Sufism, even if such people remained within the premises of the 
dervish lodge. He attracted attention to the dangers of claiming dervishness, because he believed individuals should censure themselves and keep their egos under control even when they transitioned to more elevated levels of Sufism. He noted that it was important for dervishes to avoid pride by not boasting about the acts of worship they performed. Yunus Emre warned that every person, whether scholar or ascetic, could be trapped into psychological disorders such as arrogance or hypocrisy; thus, every individual must remain careful. He indicated that people could not escape the clutches of the nafs, no matter how old they were. He thus advised that everyone should be vigilant against the frauds of the nafs.

\section{Conclusion}

Moral values become meaningful only when they are practiced. A dervish is a person who lives by moral virtues. The dervish is honest and sincere, patient and determined, tolerant and friendly. Yunus stated that a dervish completely deprives himself of worldly affairs, does not pursue his own interests, and does not act out of greed for rank and position. The dervish absorbs himself in the love of Allah and thus does not mingle love with hypocrisy. The dervish does not place value on his individual life and disregards both worlds. He does not worship for fear of hell or to attain blessings from heaven; he worships solely for his love of Allah.

In brief, according to Yunus Emre, dervishness is defined by the existence of a virtuous individual who achieves the truth by cleansing the soul of all evil and constructing a self in the light of the Qur'an and Sunnah. To be a dervish is to activate spiritual faculties that are potentially present in human nature and to have nothing but Allah in the heart.

This study overviews the concepts of Sufi and Sufism, emphasizing Yunus Emre's conception of dervishness. 
Prof. Dr. Hakan ERTíN'e Armağan ${ }^{1}$

Dervişlik dedikleri hırka ile tâc değil Gönlünü derviş eyleyen hırkaya muhtâc değil

\section{Giriş}

Evrensel ahlâkî ilkeleri esas alan İslâmiyet, toplumu meydana getiren bireylerin erdemli olmasını istemiştir. Bu çerçevede Müslümanların dürüstlük, adalet, ihsan, cömertlik, tevazu ve ahde vefa gibi erdemleri içselleştirmelerini emretmiştir. Hz. Peygamber (sav), müminleri bu konuda duyarlı olmaya teşvik etmek üzere "Sizin en hayırlınız, ahlâkı en güzel olanınızdı"’2 buyurmuştur.

İslâm düşüncesinde ihsan ve birr terimleriyle ifade edilen iyilik bütün dinlerde, felsefî ve mistik düşüncelerde önemsenir. Felsefenin amac1, mutlak iyiye ulaşıp mutluluğu elde etmektir. Dinî ilimler içerisinde en son ortaya çıkan bir disiplin olan tasavvufun amacı ise, Allah rızasını her şeyin üstünde tutan, ahlâkî değerleri özümsemiş iyi insanlar yetiştirmektir. Tasavvuf dilinde bu kişiler sûfî ya da derviş olarak isimlendirilmektedir.

Dinî ve ahlâkî değerleri yaşamak iddiasıyla ortaya çıkan tasavvuf, büyük ölçüde bu gayesini gerçekleştirmiştir. Ancak sistemleşme ve kurumsallaşma sürecinde özden sapmalar olmuş, inanç, âdâb ve erkân boyutuyla birçok farklı tarikat yapılanması teşekkül etmiştir. Tasavvuf tarihi ile ilgili eserlerde bu disiplin içerisinde yanlış yapan sûfîlerle ilgili bol miktarda malumat bulunmaktadır. Tasavvufun teşekkül sürecini yaşadığı IX-X. yüzyıllardaki bir kısım sûfî çevrelerde de benzer yanlışlıklar dikkat çekmektedir. Nitekim Serrâc (ö.378/988), Kelâbâzî (ö.380/990), Kuşeyrî (ö.465/1072), Hücvirî (ö.465/1072) ve Gazzâlî (ö.505/1111) gibi birçok âlim ve ârif kendi dönemlerinde sûfî görünümlü sahtekârlardan şikâyet ederek, gerçek tasavvufun ve sûfînin ne olduğunu yazdıkları eserlerde ortaya koymuşlardır. ${ }^{3}$

1 Evlâd-1 Fâtihân'dan derviş gönüllü bir yiğit olan Prof. Dr. Hakan ERTíN, İstanbul Üniversitesi İstanbul Tıp Fakültesi Tıp Tarihi ve Etik Anabilim Dalı öğretim üyesi olarak çalışırken 15 Mart 2021 Pazartesi günü Hakk'a yürüdü. Allah rahmet eylesin, mekânı cennet olsun.

2 Buharî, Sahih, Çağrı Yayınları, İstanbul 1992, Edeb, 38, 39.

3 Bkz. Ebû Nasr es-Serrâc, el-Luma', tahkik: Abdülhalim Mahmûd-Tâhâ Abdülbâkî Sürûr, Kahire 1960, s. 19-20; Ebû Bekir Muhammed b. İshak el-Buhari el-Kelâbâzî, et-Ta'arruf li Mezhebi Ehli 't-Tasavvuf, neşr: Arthur John Arbery, Mektebetü'l-Hanc1, 2. Bask1 Kahire 1994, s. 4-5; Abdülkerim Kuşeyrî, Kuşeyrî Risâlesi, hazırlayan: Süleyman Uludağ, Dergâh Yayınları, 3. Bask1 İstanbul 1991, s. 94-96; Hücvirî, Keşfü'l-Mahcûb, (Hakikat Bilgisi), hazırlayan: Süleyman Uludağ, Dergâh Yayınları, İstanbul 1982, s. 80-82; Ebû Hâmid Gazzâlî, İhyâu Ulûmiddin, Dâru İbn Hazm, Beyrut 2005, s. 9. 
Tarikatların ortaya çıtığı devirlerde ve günümüzde de bu zümreler arasında görülen bazı sapkınlıklar, bu kurumları töhmet altında bırakmıştır. XVII. yüzyıl sûfîlerinden Sun'ullah Gaybî’nin (ö.1087/1676'dan sonra) de vurguladığı gibi, ${ }^{4}$ özellikle şeyh konumunda olan bazı sözde sofuların manevî bir arınma yöntemi olan tasavvufu kendi çıkarları için kullanması, tarikatlara olan güveni sarsmıştır. Yaşanan gerçeklerle ideal tasavvuftaki bu yaman çelişki, tasavvuf zümreleri başta olmak üzere toplumun her kesiminde ahlâkî erdemlerin içselleştirilmesinin önemini ortaya koymuştur.

Bu çalışmada; Yunus Emre'nin ahlâkî değerleri özümsemiş bir kişi olarak tasvir ettiği derviş hakkındaki düşünceleri üzerinde durulacaktır.

\section{Yunus Emre ve Dönemi}

Anadolu irfanının önemli bir temsilcisi olan Yunus Emre (ö.720/1321), XIII. yüzyılın ikinci yarısı ile XIV. yüzyılın ilk yarısında yaşamıştır. Anadolu Selçuklu Devleti'nin zayıflayıp yıkıldığı, Osmanlı Devleti'nin kuruluş sürecine girdiği bu dönemde ülkede sosyal ve kültürel birçok faaliyet gerçekleştirilmiştir. Özellikle Anadolu dinî tarihi açısından önemli yeri olan medrese ve zâviyeler kurulup zengin vakıflarla desteklenmiştir. ${ }^{5}$ Devlet yöneticilerinin özellikle tekke ve zâviyelere olan ilgisi Irak, Horasan ve Türkistan'dan birçok sûfînin ülkeye gelmesinde etkili olmuştur. Moğol istilası sırasında da Anadolu'ya gelen birçok âlim ve ârif dinî tefekküre zenginlik kazandırmıştır. Bu dönemde Evhadüddîn Kirmânî (ö.635/1238), İbnü'l-Arabî (ö.638/1240), Necmeddin Dâye (ö.654/1256) Hacı Bektaş-1 Velî (ö.669/1271?), Mevlâna Celâleddin Rûmî (ö.672/1273) ve Sadreddin Konevî (ö.673/1274) başta olmak üzere birçok sûfî, Anadolu'da faaliyet göstermiştir. Dolayısıyla Yunus Emre'nin yaşadığı dönemde Anadolu; Horasan, Türkistan, Irak ve Şam ile Endülüs tasavvuf anlayışlarının harmanlandığı bir yer haline gelmiştir.

Anadolu'daki tasavvuf hareketlerini düşünceleriyle zenginleştiren zâhid ve sûfîler arasında İbrahim Edhem (ö.161/777), Hallâc-1 Mansûr (ö.309/922), Ebû Saîd Ebû'l-Hayr (ö.440/1049), Muhammed Gazzâlî ve kardeşi Ahmed Gazzâlî (ö.520/1126) ile Ahmed er-Rifâî (ö.578/1182) ve Ferideddin Attâr (ö.618/1221) ilk akla gelenlerdir. Ahmed Yesevî (ö. XIII. yüzyılın başları muhtemelen) ise halifeleri ve müridleriyle Anadolu'nun manevî oluşumunda büyük pay sahibidir. Dolayısıyla XIII. yüzyılda Yesevî, Kübrevî, Rifâî, Mevlevî, Bektaşî ve Ekberî sûfî gelenekleri, Anadolu'da oldukça etkili olmuştur.

4 Bilal Kemikli, Sunu'llah Gaybî Divanı, MEB Yayınları, İstanbul 2000, 115/1-33.

5 Seyfullah Kara, Anadolu Selçuklularında Din ve Dinî Kurumlar, Atatürk Üniversitesi Sosyal Bilimler Enstitüsü, Yayımlanmamış Doktora Tezi, Erzurum 2002, s. 425-462 vd. 
XIII. yüzyılda Anadolu'da görülen tasavvuf hareketleri büyük bir çeşitlilik arzeder. ${ }^{6}$ Sünnî ve gayr-i sünnî birçok unsuru içinde barındıran bu zümreleri şehir ve kırsal alanda faaliyet gösterenler olarak iki kategoriye ayırmak mümkündür. Şehirlerde faaliyet gösteren İbnü'l-Arabî, Mevlâna ve Konevî gibi sûfîler entelektüel seviyeleri yüksek âriflerdir. Dolayısıyla hitap ettikleri kesimin bilgi seviyesi yüksektir. Konargöçerler arasında faaliyet gösteren Hacı Bektaş-1 Velî, Baba İlyas (ö.637/1240) ve Baba İshak (ö.637/1240) ile Sarı Saltuk (ö.697/1297) ve Barak Baba (ö.707/1307-8) ile Geyikli Baba gibi dervişlerin muhatapları büyük ölçüde Türkmenlerdir. Bu insanlar, evliya denilince olağanüstülükleri anladıkları için kırsal alandaki sûfîler daha ziyade kerametleriyle şöhret bulmuşlardır.

Yunus Emre'nin doğduğu y1llarda Anadolu'da yaşanan iki olay ülkeyi büyük bir bunalıma sokmuştur. Bunlardan birincisi 1240'taki Babaîler İsyanı, ikincisi ise Anadolu Selçuklu Devleti ile Moğollar arasındaki 1243’teki Kösedağ Savaşı'dır. Anadolu Selçuklu Devleti'ne karşı yapılan ve ülkeyi parçalanmanın eşiğine getiren Babaîler İsyanı, Moğol İstilası sırasında Orta Asya'dan Anadolu'ya gelen Türkmen aşiretlerinin hem şeyhi hem de lideri olan Baba İlyas ve halifesi Baba İshak tarafindan düzenlenen büyük çaplı bir isyandır. Bu isyan; dinî, siyasî, ekonomik, sosyal ve psikolojik birçok sebebin bir araya gelmesiyle başlamış ve Türkiye'nin sosyal tarihinde büyük bir etki bırakmış, ülkedeki huzur ve istikrarı bozmuştur. ${ }^{7}$ Bundan üç yıl sonra gerçekleşen Kösedağ Savaşı ise, Anadolu'daki birliği tamamıyla parçalamış, hâkimiyetin fiili olarak Moğollara geçmesine yol açmıştır. Dolayısıyla Yunus Emre, Anadolu'da birliğin parçalandığı, huzur ve istikrarın kaybolduğu bir dönemde yaşamıştır.

1240'lı yılların başında doğduğu tahmin edilen Yunus Emre'nin medresede dinî ilimleri okuduğu, icâzet aldığı açık olmasa da, Risâletü'n-Nushiyye ve Divân'ındaki ifadelerinden iyi bir tahsil gördüğü anlaşılmaktadır. Ancak karakteri medrese muhitine uygun olmayan Yunus, tasavvufa yönelmiş ve Hacı Bektaş-1 Velî’nnin tavsiyesi ${ }^{8}$ üzerine gittiği Tapduk Emre'nin zâviyesinde uzun süreli zühd ve riyâzet eğitiminden sonra nefsini terbiye etmiş, aşk yolunda cezbeyi yaşamıştır. ${ }^{9}$ Şeyhine hizmeti büyük bir onur olarak gören Yunus'un ${ }^{10}$ tasavvuf terbiyesi aldığ 1 sırada tekkeye eğri bir odun getirmeyi bile uygun görmemesi, kemâlâtı elde etme yolunda ideal tasavvufu yaşama gayreti olarak değerlendirilebilir.

6 Resul Ay, Anadolu'da Derviş ve Toplum 13-15. Yüzylllar, Kitapyayınevi, İstanbul 2008, s. 16-22.

7 Ahmet Yaşar Ocak, Babaîler İsyanı, Dergâh Yayınları, 2. Baskı İstanbul 1996, s. 37-50.

8 Abdülbâkî Gölpınarlı, Vilâyet-Nâme, Menâkıb-ı Hünkâr Hacı Bektaş-ı Velî, İnkılap Kitabevi, İstanbul 1990, s. 47-48.

9 Haşim Şahin, "Yunus Emre'nin Şeyhi Tapduk Emre”, Yunus Emre, editör: A. Yaşar Ocak, Kültür ve Turizm Bakanlığı Yayınları, Ankara 2015, s. 219-221.

10 Mustafa Tatçı, Yunus Emre Dîvânı, H Yayınları, İstanbul 2020, 164/8, 208/9, 262/10, 292/8. 
Yunus Emre'nin tasavvuf öğretisi Yesevî ve Rifâî gelenekleri içerisinde şekillenmiştir. Şeyhi Tapduk Emre, Moğol istilası sırasında Anadolu'ya gelen Yesevî geleneğine mensup Buhara' 'lı Sinan Ata adlı Türk şeyhinden icazet almıştır. ${ }^{11}$ Tapduk Emre'nin Sarı Saltuk (ö.697/1297) ile Barak Baba'dan (ö.707/1307-8) da nasibi vardır. Zira Sarı Saltuk'un şeyhi Mahmud Hayranî’nin (ö.667/1269) Rifâî tarikatından icazeti bulunmaktadır. ${ }^{12}$ Barak Baba da Sarı Saltuk'un müridi olduğuna göre, ${ }^{13} \mathrm{o}$ da Rifâî ve Yesevî tarikatlarına mensup bir derviştir. Yunus'un şu ifadeleri onun Yesevî ve Rifâî tarikatlarını terkip eden bir derviş olduğunu ortaya koymaktadır. ${ }^{14}$

Yunus'a Tabdug u Saltug u Barag'dandur nasîb

Çün gönülden cûş kıldı ben nice pinhân olam

Yunus Emre, Anadolu, Azerbaycan ve Suriye taraflarına seyahat ederek halkın durumunu gözlemlemiş ve onların sevgi ve hoşgörüyle hayata tutunmalarını sağlamaya çalışmıştır.1240'ta yaşanan Babaîler İsyanı ve 1243'teki Kösedağ Savaşı sonrası Moğol istilası ile yaşama azmini kaybeden insanlara sevgi ve müsamaha ile yaklaşıp bir umut 1 şığ 1 olmuştur. ${ }^{15}$

Varduğumuz illere şol safâ gönüllere

Baba Tapduk ma'nisin saçduk el-hamdülillâh

Beri gel barışalım yâdısan biliş̧elüm

Atımuz eyerlendi eşdik el-hamdülillâh

Tasavvufta sevgi yolunu seçerek gönlünü ilâhî aşkla dolduran Yunus, şiirlerinde verdiği mesajla yüzyılların akışı içinde insanların gönlünde taht kurmuştur. $\mathrm{Bu}$ yüzden 720/1321'de 82 yaşında vefat eden Yunus'un Anadolu'nun birçok yerinde makam kabri bulunmaktadır.

\section{Yunus Emre ve Dervişlik}

Tasavvufta derviş kelimesi zâhid, fakir ve sûfî gibi çeşitli terimlerle de ifade edilir. Sûfî terimi ile ilgili tanımlarda; ahlâklı ve edepli olmak, Allah sevgisini her şeyin üstünde tutmak, halka yük olmamak, övene ve yerene farklı bakmamak ve kendileri gibi düşünmeyenleri ötekileştirmemek dikkat çeker. İslâmiyet'in ahlâk anlayışını yaşatmaya çalışan, nazariyeden çok amele önem veren bir disiplin olan tasavvufla ilgili tanımlarda ise, ilim amel bütünlügüune dikkat çekilerek, ahlâkî erdemlerin

11 M. Fuad Köprülü, Türk Edebiyatında İlk Mutasavvıflar, DİB Yayınları, 4. Bask1 Ankara 1981, s. 266.

12 Muhammed b. Ali b. es-Serrâc, Tuffâhu'l-Ervâh ve Miftâhu' 'lírbâh, hazırlayanlar: Nejdet GürkanMehmet Necmettin Bardakçı-Mehmet Saffet Sarıkaya, Kitapyayınevi, İstanbul 2015, s. 319-327.

13 Ahmet Yaşar Ocak, "Barak Baba”, Diyanet İslâm Ansiklopedisi, c. V, s. 61-62, İstanbul 1992.

14 Tatç1, Yunus Emre Dîvânı, 201/41.

15 Tatçı, Yunus Emre Dîvânı, 292/4-6. 
sözle anlatılmaktan ziyade yaşandığı takdirde anlamlı olacağ vurgulanır. ${ }^{16} \mathrm{Bu}$ ifadelerden hareketle dervişin; Allah'a teslimiyet ve tevekkül anlayışını içselleştiren, her şeyin sahibinin Allah olduğu bilinciyle hareket etmekle birlikte insan olarak sorumluluklarını yerine getiren, ihtiyaçlarını sadece Allah'tan isteyen, kalbini olumsuz düşüncelerden, dilini kötü sözlerden koruyup güzel şeyler söyleyen, elinden geldiği kadarıyla muhtaç kimselere iyilik yapan kişi olduğu söylenebilir.

Tasavvufun ve dervişliğin temeli; insana değer vermek, yaratılanı yaratandan dolayı sevmektir. Gönül zenginliği, cömertlik, insanlarla iyi geçinmek, içe doğan şeylere vakıf olmak, doğruluktan asla ayrılmamak, samimi ve dürüst olmak, her anın kıymetini bilmek ve dünyaya dalmamak da dervişin vasıflarıdır. ${ }^{17} \mathrm{Bu}$ nitelikler dervişin sözünün ve davranışlarının Hz. Muhammed'in (sav) sünnetine uygun olmasını, insanların kusurlarını görmezlikten gelmesini ve hataları bağışlamasını, edepli ve ahlâklı olmasını gerektirir. Söz, davranış ve halleri Kitap ve Sünnet'e uymayan kişilerin dervişlik davasında bulunması uygun değildir.

Tasavvufun şahsiyet eğitiminde ahlâkî değerlerin önemi büyüktür. Bilgelik yoluna giren kişilerin ilkin riya, haset, kibir ve kendini beğenme gibi olumsuz hasletleri terk etmeleri, sonra da adalet, iyilik ve ahde vefa gibi erdemleri kazanmaları istenir. Yunus Emre de; "Evvel bize vâcib budur hoş hulk ile amel gerek, İslâm adı okunıcak yoldaşımız iman gerek" diyerek, ${ }^{18}$ dervişliğin temelinin ahlâk olduğuna dikkat çeker. Yunus'un bu yaklaşımı, Kur'ân'ın indiriliş sürecine uygun bir yöntemdir. Nitekim Mekkî surelerde tevhîd, bilgi ve akılla tefekkürün önemi vurgulanmakta, adalet, iyilik yapmak, iffetli olmak, ahde vefa, dürüstlük ve sabır gibi ahlâkî değerler sistemi üzerinde durulmaktadır. ${ }^{19}$ Namazın Mekke devrinin sonlarında Mi'râc gecesinde, zekâtın hicrî ikinci yılda farz kılındığg dikkate alındığında, Yunus'un ahlâkı önceleyen bu tespitinin isabeti daha iyi anlaşılır. ${ }^{20}$

16 Serrâc, el-Luma', s. 45-46; Kuşeyrî, Risâle, s. 451-453; Hücvirî, Keşfü'l-Mahcûb, s. 122-123

17 Takiyyüddîn Abdurrahman Ebû'l-Ferec ibn Abdi'l-Muhsin el-Vâsıtî (674/1275-76-744/1343), Tiryâku'l-Muhibbîn fi Tabakâti Hırkati' 'l-Meşâyihi 'l-Ârifin, Matbaatü'l-Behiyye, Kahire 1305h., s. 34-35; Hacı Hüsâm İbrahim b. Muhammed Kâzerûnî, Sifâü'l-Eskâm fì Sîreti Gavsı'l-Enâm Ahmed er-Rifâî Menkıbeleri, çeviren: Nurettin Bayburtlugil-Necdet Tosun, Vefa Yayınları, İstanbul 2008, s. 118-125.

18 Tatç1, Yunus Emre Dîvânı, 138/1-5.

19 Nahl, 16/90-91, 125-127; Lokman, 31/13-19.

20 Ancak bu yöntemin klasik metinlerde dikkate alınmadığı görülür. Nitekim hadis ve fikıh literatürü ile ilmihal kitaplarında ahlâk ve edeple ilgili bölümler arka sıralarda yer almaktadır. Örnek olarak; Buharî'nin Sahîh'inde Âdâb 78, Rikâk 81, Müslimin Sahîh'inde ise (Çağrı Yayınları, İstanbul 1992) Âdâb 38, Birr ve's-S1la ve'l-Âdâb 45, Zühd ve'r-Rekâik 53. bölümlerde yer almıştır. Müslümanların ahlâkî değerleri içselleştiremeyişinin, ibadetlerin iç boyutundan daha çok şekil kısmına önem vermelerinin arka planında bu yaklaşımın etkisinin olduğu söylenebilir. $\mathrm{Bu}$ durumun farkına varıp çözüm önerisi sunanlardan biri Yunus Emre'dir. 
Yunus Emre'nin tasavvuf düşüncesi; Hz. Peygamber'in şahsında somutlaşan Kur'ân ahlâkını benimseyen sûfîlerin melâmet, cezbe ve aşk anlayışları ile dürüstlük, iyilik, hoşgörü ve incinmemek gibi erdemlerin terkibinden oluşmaktadır. Dolayısıyla ona göre insan, özelde derviş, her şeyden önce dürüst, samimi, güvenilir ve ahlâklı olmalıdır. "Allah'in velîlerine korku ve hüzün yoktur" 21 ayetinde övülen dostlardan olabilmek için, Kur'ân'da vurgulanan ve Hz. Peygamber'in önemsediği ahlâkî erdemleri özümsemelidir.

Yunus Emre, tıpk1 Râbia Adeviyye (ö.185/801) ve Hallâc-1 Mansûr gibi sevgiyi her şeyin başına yerleştirir ve ilâhî bir mevhibe olarak değerlendirir. İyi bir insan olmak ve hakikate ulaşmak için meşrebine uygun aşk yolunu seçer. Tasavvufta aşk ve cezbe yolu, Allah'a ulaştıran en kısa yol olmakla birlikte tehlikesi ve zorlukları çoktur. Ferideddin Attâr'ın (ö.618/1221) Mantıku 't-Tayr' da sembolik olarak anlattı̆̆1 bu yolda, vuslata erebilmek için aşılması gereken sarp yokuşlar, dağlar, vadiler ve denizler ancak güçlü bir irade, sabır ve tevekkülle aşılabilir. Mevlâna da bir mirasyedinin rüyasında gördüğü hazineye ulaşmak için katlandığı zorlukları dile getirip, gülü elde edebilmek için dikene, lütfa kavuşmak için kahra katlanmak gerektiğini vurgulayarak, ${ }^{22}$ aşk yolundaki engellerin kolay geçilmediğini belirtir. Bütün bu zorluklara rağmen Yunus Emre aşk yolunu seçmiş ve bir ülkü uğruna yola düşen kişinin amacını gerçekleştirebilmek için canını dişine takarak çok çalışması gerektiği bilinciyle yolun sıkıntılarına katlanarak vuslatı gerçekleştirmiştir.

Yunus Emre'nin öğretisinde dervişin bir diğer adı âşıtır. Âşık ise hakikate ulaşma yolundaki bütün engelleri aşarak hakikate ulaşan kişidir. İdealini gerçekleştirmek için yolun zorluklarına katlanmayanlar sahte âşıklara benzer. Çünkü âşı, Hak yolunda kınayanın iğneleyici sözlerine aldırmadan, kin ve nefret ile hırs ve tamahı gönlünden çıkarıp dost sevgisini yerleştiren kişidir. ${ }^{23}$ Dolayısıyla Allah rızasını her şeyin üstünde tutan derviş, cennet umudu veya cehennem korkusunu bir hicap olarak görür ve sadece Allah'a kavuşmayı ister.

Hakk'ı arayıp bulmaya çalışan kişi, her şeyden önce nefsini terbiye ederek gönlünü derviş eylemelidir. Yunus Emre'ye göre bunun yöntemi, dervişliğe soyunan kişinin, bir mürşidin terbiyesine girip teslimiyet ve tevekkülle hareket ederek tartışmalardan uzak durması, mal ve mülk sevgisini gönlünden çıkarmasıdır. Bu süreçte sâlik sabır ve kanaati azık edinmeli, kahrı ve belayı şikâyet etmeden kabullenmelidir. ${ }^{24}$ Ancak bunların gerçekleştirilmesi zorlu bir gayret ve sabır ister.

21 Yunus, 10/62.

22 Mevlâna, Mesnevî, VI/4207-4336.

23 Tatçı, Yunus Emre Dîvânı, 27/1-3.

24 Tatç1, Yunus Emre Dîvânı, 97/1-5, 123/1-7, 140/1-8. 
Bu bakımdan dervişlik yoluna çıkan kişi, sabırlı ve mücadelesinde kararlı olmalıdır. Çeşitli bahaneler ileri sürüp yoldan dönmemeli, karşısına çıkan engelleri aşmak için bütün gayretini sarf etmelidir. Bir zorluk ile karşılaştı̆̆ında, gülü sevenin dikenine katlanacağı bilinciyle hareket edip, her zorluğun yanında bir kolaylık, zehrin yanında panzehir olduğunu düşünerek yoluna devam etmelidir.

Dervişlik, ibadet, zikir, evrâd ve riyâzetlerle nefsi terbiye ederek yeni bir benlik inşa etme yöntemidir. ${ }^{25} \mathrm{Bu}$ süreçte derviş; tevekkül ve teslimiyet, dürüstlük ve samimiyet, ahde vefa, kanaatkârlık ve cömertlik gibi erdemleri özümseyerek iyi bir şahsiyet sahibi olur. "Hakk’ ' bulmak isteyenler eylesin nefsini derviş"26 ifadesinden de anlaşıldığı gibi, dervişlikte asıl olan nefis tezkiyesidir. Nefsinin emrinde koşan, aşk şarabını içmeyen, katı kalbini yumuşatmayan kişiler, Hakk'a yakınlık elde edemez, Allah'ın rahmetinden faydalanamaz. Tasavvufta dört kapı kırk makam olarak ifade edilen şeriat, tarikat, marifet ve hakikat menzillerinin zorluklarla çevrili olduğunu belirten Yunus Emre de, Hakk'a yakınlığ1 sağlayan nefis terbiyesinin uzun süreli bir gayret gerektirdiğini vurgular. ${ }^{27}$ Tasavvuf terbiyesinde ilk kap1 olan şeriatın kuralları yerine getirilmeden tarikata girilmez, dolayısıyla mârifete ve hakikate erilmez.

Yunus Emre, "Hak bir gönül verdi bana, hâ demeden hayrân olur. Bir dem gelir şâdân olur, bir dem gelir giryân olur" ${ }^{28}$ ve "Bu fenâ mülkünde ben nice hayrân olam" ${ }^{29}$ şeklinde başlayan şiirlerinde, tam kemâle eremeyişin ıstırabını dile getirir. Tasavvuf terbiyesini tamamlamakla birlikte henüz telvîn makamından temkin makamına geçememenin, aşk deryasında kendisinden bile habersiz olarak hayret içinde kalmanın psikolojisini dışa vurur. Çünkü bu hali yaşayan derviş, renkten renge girer, halden hale geçer. Telvîn makamında korku ve ümit, hasret ve vuslat, keder ve sevinç gibi çeşitli haller birbirini takip eder. ${ }^{30} \mathrm{Bu}$ makamda kalbin sürekli değişkenliğine dikkat çeken Yunus, bunu dünya hayatında yaşanan iniş çıkışlara benzetir. Bazen melekler gibi tertemiz, bazen şeytana parmak 1sırtan çok çirkin bir varlığa dönüşmenin mümkün olduğunu ifade eder. Organların kralı olan kalp, Allah'ı bilip emirlerine itaat ederek iyilikler yaptığı zaman, insanı arş-1 Rahmân'â çıkarır, Allah'a isyan ederek çirkin ve kötü işler işlediğinde, cehennemin en derin

25 Metin Yasa, "Yunus Emre'de Ben Bilinci: Ben Ötesi Psikolojisi Açısından Bir Değerlendirme", Uluslararası Yunus Emre Sempozyumu Bildirileri, İstanbul 2010, s. 72-76.

26 Tatçı, Yunus Emre Dîvânı, 123/1.

27 Tatçı, Yunus Emre Dîvânı, 295/5, 351/1-7.

28 Tatçı, Yunus Emre Dîvânı, 49.

29 Tatçı, Yunus Emre Dîvânı, 201.

30 Mehmet Kaplan, “Telvin”, Türk Edebiyatı, say1: 193, Yunus Emre Özel Say1s1, İstanbul 1989, s. 4-6. 
çukuruna düşürür. Gönlün bazen hikmetlere dalacağını belirten Yunus, bazen de isyan bayrağını çekeceğini, bazen günahını düşünüp cehenneme gitmeyi hak ettiğini, bazen de Hakk'in rahmetinin genişliğini tefekkür ederek cennete girmeyi ümit edeceğini vurgular. Böylece o, bir taraftan güzel ahlâkı içselleştiren dervişliği, diğer taraftan insan karakterinin zaaflarını açığa çıkarmak suretiyle ruh halinin değişkenliğine dikkat çeker.

Yunus'un aşk yolunda akı1, insana belli bir yere kadar rehberlik eder. Tevhîd, fenâ ve cem gibi tasavvufî birlik tecrübelerinin yaşandığı süreçte akıl değil, aşk devreye girer. Dolayısıyla aşk deryasına dalanın gemiye ve öğüde ihtiyacı yoktur. Çünkü bu mertebede âşık ve mâşûk ortadan kalktığı için aşkın dışında bir yardımcı bulunmaz. Yoldaşı aşk olan derviş, her nereye dönerse orada aşk1 görür. ${ }^{31}$ Tevhîd tecrübesini yaşadığı sırada benlik duvarını aşan derviş, görünürde var olmakla birlikte şuur olarak kendi yokluğunu hisseder. Bu esnada dervişin durumu, güneş doğduğunda görünmeyen yıldızlara benzer. Aslında yıldızlar bir yere gitmiş değildir. Daha güçlü ışık onların 1şığını hükümsüz kılmıştır. Mevlâna bunu, güneş çıktığında ışığının bir anlamı kalmayan muma benzetir. ${ }^{32}$ Dolayısıyla derviş tıpkı bu mum gibi kendinde varlık hissetmeyen, iddia sahibi olmayan diğerkâm kişidir. ${ }^{33}$ Ancak bu durum, onun toplum tarafından deli olarak nitelendirilmesine yol açabilir. Böyle ithamlarla karşılaşan âşık, itibarsılaş̧ırılmayı göze alabilmeli, eleştirenlerin sataşmasına aldırmadan Hak bildiği yolda yürüyebilmelidir.

Aşk yolunda yürüyen kişinin, tasavvuf terbiyesinin gerektirdiği zikir, evrâd riyâzet ve uzlet gibi uygulamaları yaparak nefsini tezkiye edip kalbini kötülüklerden arındırdıktan sonra bir adım daha atması gerekir. Aşk yolunda yapılması gereken bu şey, canı feda etmektir. Nitekim "Cânını aşk yoluna vermeyen âşık mıdır? Cehd eyleyip ol dosta ermeyen âşık mıdır?" 34 diyen Yunus, Kur'ân'da övülen gayret, fedakârlık ve kararlılığ dervişlikte temel şart olarak görür. Bunları içselleştirip hayatına yansıtmayan kişilerin bu yolda işlerinin olamayacağını dile getirir. Herkesin yaptığı davranışın kendi kimliğini ortaya çıkaracağını belirten Yunus, dervişliğin güzel söz söylemek değil, ahlâkı yaşamak olduğunu vurgular. Ancak bazı insanların bu ölçüye göre hareket etmediklerinin de farkındadır. Bu yüzden derviş olduklarını söyleyip gereğini yapmayanların Cemâl-i ilâhîyi göremeyeceklerini ifade ederek, dervişlikte söz ile davranışın uyumuna dikkat çeker. ${ }^{35}$

31 Abdülbâkî Gölpınarlı, Yunus Emre ve Tasavvuf, İnkılap Kitabevi, 2. Baskı İstanbul 1992, s. 435, CXXIII/1-2.

32 Mevlâna Celâleddin Rûmî, Mesnevî, çeviren: Derya Örs-Hicabi Kırlangıç, Türkiye Yazma Eserler Kurumu Yayınları, İstanbul 2015, III/3661-3665.

33 Şefik Can, Hz. Mevlânâ'nın Rubâîleri, Kültür Bakanlığı Yayınları, Ankara 2001, R. 409.

34 Tatç1, Yunus Emre Dîvânı, 36/1.

35 Tatçı, Yunus Emre Dîvânı, 335/10-11. 
İlk dönemlerden itibaren sûfîler, Kur'ân ve Sünnet tarafından sınırları belirlenen ahlâklı bir hayat yaşamayı önemsemişlerdir. Ancak bir kısım tasavvuf zümrelerinin erdemlerden söz etmekle birlikte, hırka ve tâc giyerek sûfî oldukları izlenimi verip şekilciliğin dar kalıplarına sıkıştıkları görülür. Tasavvufta asıl olan, niyetin ve kalbin saflı̆̆ıdır. Yunus'un “Dervişlik dedikleri hırka ile tâc değil, Gönlünü derviş eyleyen hırkaya muhtâc değil" ${ }^{36}$ ifadesinde de görüldüğü gibi, bir gönül işi olan dervişlik, sırta yamalı hırka ve başa çeşitli sayılarda terkli tâc giymekle elde edilmez. İyi bir derviş olmanın yolu, nefse acizliğini hatırlatıp Allah'a kulluğu öğretmektir. Çünkü dervişlik, varlık düşüncesini zihinden çıkarıp Hakk'a boyun eğmektir. Gönlündeki benlik duvarını yıkıp yeni bir kimliğe bürünerek Hak ile tevhîd tecrübesi yaşamaktır. Ancak bu tecrübenin dile gelmeyeceği akıldan çıarılmamalıdır. Yunus Emre bunu şöyle ifade eder:

Bu bir acâyib haldir bu hale kimse ermez

Âlimler dava kllar velî değme göz görmez

Ilim ile hikmet ile kimse ermez bu sirra

Bu bir acâyib sirdır ilme kitaba slğmaz. ${ }^{37}$

Yunus'un cezbesinin ağır bastığı sırada yaşadığı tevhid tecrübesi, kalben yaşadığı manevî bir şuur düzeyidir. Bu tecrübe sırasında dervişin yaşadığı haller, kitaplardan okunarak elde edilmez. Allah'ın bir mevhibesi olan bu hale zahirî bilgiyle erişilmez. Dolayısıyla ulemanın tasavvufî haller konusundaki sözleri, tecrübeye dayalı olmayan, ilme'l-yakîn düzeyinde bilgilerdir.

Ahlâkî değerler, yaşandıkları zaman anlamlı olur. Derviş de ahlâkî erdemleri yaşayan, dürüst ve samimi, sabırlı ve kararlı, müsamahalı ve cana yakın kişidir. Yunus'un da belirttiği gibi, dünyayı tümüyle gönlünden çıkaran derviş, çıkar peşinde koşmaz, makam ve mevki hırsıyla hareket etmez. ${ }^{38}$ Allah sevgisini özümsediği için aşka riya karıştırmaz. İnsan olarak sınırının farkına varıp erenlerin huzurunda sofuluk gösterisi yapmaz. Candan ve iki cihandan geçen derviş, cennet nimetleri ya da cehennem korkusundan dolayı değil, sadece Allah'1 sevdiği için ibadet yapar. Şeriat ve tarikatın hakikate ulaştırdığı bilinciyle hareket ederek mârifetullahı elde eder. ${ }^{39}$ Neticede her geceyi Kadîr, her geçeni Hızır bilecek bir seviyeye gelerek, Hakk'ın rızasını ve cemâlini görmenin dışındaki şeylere iltifat etmez.

Yunus Emre'nin önemsediği ve bir vasfi haline getirdiği tevazu, kibirle zillet arasında bulunan bir erdemdir. Tevazu, bir miskinlik olmayıp alçakgönüllü ve

36 Tatçı, Yunus Emre Dîvânı, 162/1-2.

37 Tatçı, Yunus Emre Dîvânı, 110/1-2.

38 Tatç1, Yunus Emre Dîvânı, 97/1-5.

39 Gölpınarl1, Yunus Emre ve Tasavvuf, s. 385, XXXIII/1-2. 
vakarlı duruşu ifade eden bir terimdir. Bu bakımdan insan ne büyüklük taslamalı, ne de kendini değersiz göstermelidir. Ancak bazen dervişler arasında da farklı sebeplerden ötürü miskinliği seçerek başkalarına yük olan ya da kibirlenip ortalığ 1 kan gölüne çevirenlere rastlanmaktadır. Nitekim Anadolu Selçuklu Devletine karşı kendilerinin bir güç olduğunu ortaya koyarak isyan eden Türkmen babaları böyle bir eylemi gerçekleştirmiştir. Yunus Emre, Babaîler İsyanı ile ülkede açılan yaraları tevazu ile tedavi etmeye çalışır. Zira tevazu, hem Allah ile olan ilişkilerde hem de sosyal hayatta önemli bir ahlâkî değerdir. Yunus; "Er oldur alçakta dura yüksekten bakan göz değil" ve "Kamusun bir gör kemterin er gör" hiç kimseyi küçük görmemek gerektiğine dikkat çeker ve alçakgönüllü bir şekilde insanlara yaklaşarak hayata tutunmalarını sağlamaya çalışır.

Sosyal hayattaki ilişkilerde tevazu ve samimiyetin yapıcı bir özelliği de vardır. Tepeden bakan bir tavırdan uzak durmak, muhataba değer vermek, gönül alıcı sözler söylemek insanlığın bir gereğidir. İnsanlar hatalarının yüzlerine vurulmasından hoşnut olmazlar. Bu yüzden Hz. Peygamber sahabeden yanlış yapanları bazen yalnız olarak bulundukları sırada uyarmış, bazen de mescidde isim zikretmeden kötü davranışa dikkat çekerek kimsenin onurunu incitmemiştir. Kendisine gelip haram bir şeyi yapmak için izin isteyenleri de bu işin yanlışlığını anlatarak vaz geçirmiştir. ${ }^{42}$ Yunus Emre de "Tehî görmen kimseyi hiç kimesne boş değil, Eksiklik ile nazar erenlere hoş değil" "43 ifadesiyle, insanların kusurlarını görmemeyi tercih etmiştir. "Kişi bile söz demini, demeye sözün kemini, Bu cihan cehennemini sekiz uçmak ede bir söz" ${ }^{\prime 4}$ diyerek, dervişin, güzel bir sözün zehirli aşı şifalı bala, karamsarlığı umuda dönüştürdüğü bilinciyle hareket etmesi gerektiğini belirtmiştir. Yunus, kötülüğe karşı1ık vermenin insanın bir hakkı olmakla birlikte bağışlamanın büyük bir erdem olduğunu vurgulayan âyetten ${ }^{45}$ aldığı ilhamla dervişin, gözüyle gördüğünü eteğiyle örten, kusurları görmezden gelen ve yapılan kötülükleri bağışlayan, insanları olduğu gibi kabul eden kişi olduğunu belirtir. ${ }^{46}$ Derviş, kendisine kötülük yapsalar da, tıpk1 Hz. Peygamber gibi bağışlamayı bilmelidir. Çünkü derviş, Peygamber mirasına sahip çıktığını söylemektedir. Bu yüzden derviş; benlik iddiasını bırakıp diğerkâm, geniş gönüllü, şefkatli, müsamahalı ve sevecen olmalıdır. Yunus bu düşüncesini; "Derviş gönülsüz gerekdir söğene dilsiz gerekdir, Döğene elsiz gerekdir halka

40 Tatçı, Yunus Emre Dîvânı, 166/3.

41 Tatç1, Yunus Emre Dîvânı, 353/3.

42 Ahmed b. Hanbel, Müsned, Çağnı Yayınları, İstanbul 1992, c. V, s. 256-257; c. VI, s. 461.

43 Tatç1, Yunus Emre Dîvânı, 167/1.

44 Tatçı, Yunus Emre Dîvânı, 102/5.

45 Şûrâ, $42 / 40$.

46 Tatç1, Yunus Emre Dîvânı, 167/1-5. 
berâber gerekmez"47 sözleri ile hayata geçirmiş, dervişin, lütfu da kahrı da Allah'tan bilip hoş göreceğini vurgulamıştır.

Allah rızası için yapılan işleri tıpkı peygamberlerin yaptığı gibi Allah'a ircâ etmek, kötü bir davranışla yüz yüze gelindiğinde nefse yüklemek tevazuun gereğidir. Yunus Emre de böyle bir bakış açısıyla hareket ederek hiçliği seçer ve dervişliğin manevî hallerini Allah'ın bir ihsanı olarak nitelendirir. ${ }^{48}$ Tasavvufta fenâfillah mertebesine yükselmesine rağmen, diğerkâm bir tavır sergiler ve bu mertebeye ulaşmak için tekkede uzun süreli yaptığı hizmetleri, nafile ibadet, zikir ve riyâzetleri aklına bile getirmez.

Yunus'un sevgi ve hoşgörü anlayışı sadece kendi muhiti ya da Müslümanlarla sınırlı olmayıp herkesi kuşatır. Bu yüzden şiirlerinde mezhep ve meşrep ayrımı yapmadan tüm Müslümanlara iyiliği, dürüstlügü ve yardımlaşmayı tavsiye eder. Potansiyel Müslüman adayı olan diğer dinlere mensup olanlarla karşılaştığında, şefkat ve merhametle yaklaşarak, erdemli davranışlarıyla tevhîd anlayışını benimsetmeye çalışır. Onun bu tavırlarının arka planında şu ayetler vardır. Yüce Allah Hz. Muhammed'e: "Rabbinin yoluna hikmetle ve güzel öğ̈̈tle çă̆ır. Onlarla en güzel şekilde mücadele et, tartış" gidin. Çünkü o çok azdl. Fakat ona tatlı dille, nezaketle söz söyleyin" ${ }^{50}$ diyerek, Firavun'u tatlı dil ve nezaket içerisinde İslâm'a davet etmelerini istemiştir. Çünkü eğitimcinin topluma yararlı işler yapması, kötülük yapana bile iyilikte bulunması, toplumun eziyetlerine sabırla katlanması güzel bir erdemdir. "Fakat bu meziyet, sadece yüksek ahlâk ve faziletten nasibi olan sabırlı kimselere verilir."

Kur'ân'ın önemsediği bu erdemleri hayata geçiren Yunus Emre, “Aşk mezhebi dindir bana" ${ }^{52}$ diyerek, tıpk1 Âşı Paşa (ö.733/1332) gibi, ${ }^{53}$ XIII. yüzyılda Anadolu insanının parçalanmışlığını sevgi ile birleştirmeye çalışır. Aşk yolunda yürüyen dervişin din ve millet ayrımı yapmayacağını belirterek, herkese aynı gözle bakar ve tüm insanlığa hayır dua eder. ${ }^{54}$ Dolayısıyla insana makam ve mevkiinden dolayı değil, sahip olduğu insanlık şerefi sebebiyle değer verip saygı duymak

47 Tatçı, Yunus Emre Dîvânı, 111/1-2.

48 Tatçı, Yunus Emre Dîvânı, 324/1-5.

49 Nahl, 16/125.

50 Tâhâ, 20/43-44.

51 Fussilet, 41/35

52 Tatçı, Yunus Emre Dîvânı, 7/1.

53 Âşık Paşa, Garib-Nâme, hazırlayan: Kemal Yavuz, Türk Dil Kurumu Yayınları, İstanbul 2000, c. I/1, s. 63/7-9, 67/10-11, 69/1-4.

54 Tatçı, Yunus Emre Dîvânı, 236/1-3. 
gerekir. Bugün Müslüman olmayan birinin yarın iman ederek büyük mertebeler kazanabileceği düşüncesiyle farklı dinlerdeki insanlara da nezaket, sevgi ve hoşgörüyle yaklaşmalıdır.

Hak ile vuslatı hedefleyen âşık için ayrılık, en büyük 1stıraptır. Vuslat ise en büyük mutluluktur. Âşık ile mâşûğu nehir ve denizle sembolize eden Yunus Emre, Hak yolundaki müridi nehre, şeyhi denize benzetir. ${ }^{55}$ Nehrin denize varabilmesi için birçok engeli aşması gerekir. Denize ulaşan nehir artık onun rengine boyanır. Dolayısıyla kendisini feda eder. Bunu göze alamayan kişiye âşık denilmez. ${ }^{56}$ Çünkü dervişlik, hem candan hem de iki cihandan geçip vuslata talip olmaktır. ${ }^{57} \mathrm{Bu}$ ümitle çıktığ 1 yolda hedefine ulaşıp fenâfillah halini yaşayan dervişin gözü açık, gönlü temiz, kulağ1 Allah ve peygamber sözüne âş̧ktır. Dolayısıyla dervişlik yolunda nefsini feda eden, doğruluktan ve dürüstlükten taviz vermeyen, cömert ve samimi insanlar yürüyebilir. ${ }^{58}$ Allah'a vuslatı gerçekleştiren dervişin, kendisi de dâhil gözünde hiçbir şeyin kıymeti yoktur. Çünkü o, en büyük hazine olan mârifetullaha erişmiş, gerçek saadet olan Allah'a kavuşmuştur. ${ }^{59}$

Cânlar cânını buldum, bu cânım yağma olsun Assı ziyandan geçtim, dükkânım yağma olsun Ben benliğimden geçtim, gözüm hicâbım açtım Dost vaslına ulaştım, gümânım yă̆ma olsun Yunus ne hoş demişsin, bal u şeker yemişsin Ballar balını buldum, kovanım yağma olsun

Netice itibariyle Yunus Emre'ye göre dervişlik; Kur'ân ve Sünnet 1şığında nefsi kötülüklerden tezkiye edip benliği inşa ederek iyi bir insan olmayı ve hakikate ulaşmayı sağlamaktır. Dervişlik, insanın fitratında potansiyel olarak mevcut olmakla birlikte örtülü kalan manevî melekeleri harekete geçirmek, gönülde Allah'tan başka bir düşünceye sahip olmamaktır. Derviş de şefkat ve merhamet, sevgi ve hoşgörü, cömertlik ve bağışlama gibi ahlâkî erdemleri bilfiil yaşayan kişidir.

\section{Yunus Emre'de Dervişlik Eleştirisi}

Tasavvufun şahsiyet eğitiminde insanın kendinin sınırlarını bilmesi önemlidir. Sâlik'in yaptığı ritüellere değer verip kendini beğenerek böbürlenmesinin önüne geçmek üzere nefis muhâsebesi ve nefis mücâhedesi yöntemleri uygulanmaktadır.

55 Tatç1, Yunus Emre Dîvâni, 229/3.

56 Gölpınarl1, Yunus Emre ve Tasavvuf, s. 444, XXLII/1-2.

57 Tatç1, Yunus Emre Dîvânı, 167/4.

58 Tatç1, Yunus Emre Dîvânı, 239/1-9.

59 Tatç1, Yunus Emre Dîvânı, 271/1-2, 8. 
"Ben nefsimi temize çekemem. Çünkü nefis daima kötülüğü emreder" ${ }^{60}$ ayetinden hareket edilerek, nefse karşı tedbirli olunması tavsiye edilmektedir. Her günün sonunda yaptıklarıyla hesaplaşan sûfînin, hareketlerini kontrol ederek hata yapmamaya çalışması, ölmeden önce ölme şuurunu yakalaması istenmektedir. Ancak dervişin, tasavvufta üstün bir mertebeye yükselmesine rağmen, günah işleyerek bütün kazanımlarını kaybetmesi de mümkündür. Şeyh-i San'ân hikâyesi bunun dikkate değer bir örneğidir. ${ }^{61}$ Yunus Emre de birçok şiirinde bu duruma değinerek dervişleri yanlış yapmamaları konusunda ikaz eder. Çünkü derviş de bazen kendi yaptığı zikir ve evrâdın çokluğuna bakarak diğer insanları küçümseyebilir.

İnsan, insanın aynasıdır. İyi bakan iyi, kötü bakan ise kötü görür. Başkasında görülen kusurlar, aslında insanın kendi ayıplarıdır. Ancak insan bunları kendisine yakıştıramadığ için onları ayıplar. Bunun farkında olan Yunus Emre; "Yunus senin ayıbını gözlegil ayrugı ko, Kimsenin ayıbına sen bakmagil yazıkdı"' ${ }^{2}$ diyerek, başkasının eksik ve kusuru ile ilgilenirken kendisini unutan dervişe, kendi hatalarına bakmasını ve onları düzeltmesini ögütler. Çünkü insanın kendi kusurunu görüp telafi etmesinden daha değerli bir şey yoktur. Yaptığı özeleştiriler ile dervişin kendini beğenme, riya ve kibir gibi kötü duygulardan uzak durmasını sağlamaya çalışan Yunus Emre, böylece hem nefsini dizginler, hem de dervişlerin bu konuda dikkatli olmalarını ister. ${ }^{63}$

Sofiyem halk içinde tesbih elimden gitmez

Dilim mârifet söyler gönlüm hiç kabul etmez

Boynumda icâzetim riyâ ile tâatim

Endişem ayruk yerde gözüm yolu gözetmez

Yunus'un sözde sofular gibi ahlâk ve erdemlerden yoksun olduğunu belirtmesi, melâmetî anlayışı benimsemesinden kaynaklanmaktadır. Onun, dervişlerin de yaptıkları ibadet ya da iyiliklerle övünüp kibir ve riyâ gibi psikolojik rahatsılılklara yakalanabileceğine dikkat çekmek düşüncesiyle böyle bir yöntemi benimsediği söylenebilir. Zira tasavvuf eğitimi sürecindeki derviş, halvette kaldığı süreçte yaptı̆̆ zikir ve evrâdı çok görmeye başlayabilir. Kendisi gibi riyâzet uygulamayan, zikir ve nafile ibadet yapmayanları düşünerek kendini beğenme krizine saplanabilir. Bu da onun kabz haline düşmesine sebep olabilir. Yunus Emre özeleştiri yaparken dervişliğin kurallarını yerine getiremediğini, nefsini terbiye edemediğini, kibir ve

60 Yusuf, 12/53.

61 Ferideddin Attâr, Mantıku 't-Tayr, çeviren: Abdülbâkî Gölpınarlı, MEB Yayınları, İstanbul 1990, c. I, s. 97-127 (beyit no: 1197-1607).

62 Tatçı, Yunus Emre Dîvânı, 86/7.

63 Tatçı, Yunus Emre Dîvânı, 117/1-2, 6, 9. 
riyadan kurtulamadığını dile getirip, bu hataya düşmemeye çalışır. Evrâd ve ezkârın çokluğunu düşünmenin manevî gelişmeye engel olduğu bilinciyle eksiklerini gidermeye çalışmayı daha doğru bulur. ${ }^{64}$

Yunus Emre'ye göre insan, Allah'ın murâkabesi altında olduğunun bilinciyle hareket etmelidir. Tasavvufta önemli mertebeler kazansa da, nefsin dizginlerini sağlam tutmayı sürdürmelidir. Bunun da en etkili yollarından biri manevî kalp hastalıklarından "ucb"a yakalanmamaktır. Bu düşünceyle hareket eden Yunus, insanların kendisine baktıklarında bir şeyh olarak gördüklerini, günah işlemeyen bir insan diyerek hürmet ettiklerini, ancak kendisinin diş görünüm itibariyle dervişe benzemesine rağmen bu saygıyı hak etmediğini ifade ederek, nefsini kınamayı sürdürür. Dervişlerin giysilerini giymesine rağmen hep gizlice günah işleyip hata ve isyankârlık içinde bir ömür geçirdiğini belirterek, derviş olduğu halde yanlış yapanlara mesaj verir. ${ }^{65}$

Görenler elim öper tâc u hırkaya bakar

Şöyle sanırlar beni zerrece günah etmez

Dışım derviş içim boş dilim tatlı sözüm hoş

Illa ben ettiğimi dinin değişstiren etmez

Yunus'un bu ifadelerinde insanın psikolojik hallerini analiz eden bir durum tespiti dikkat çekmketedir. Çünkü insan, Allah'ın kendisine verdiği ilim ve irfan, mal ve mülk gibi zenginliklerle yaşarken, bazen zâhir-bâtın bütünlügünü ihmal edebilmektedir. Diliyle zikir yaparken, gönlünde mal sevdası depreşmektedir. İbadette huşûyu yakalayamadan şekil olarak tamamlamaktadır. Başkası hakkında kötü düşünmekte fakat eyleme dönüştürecek firsat bulamadığ 1 için düşündüğü şeyi yapamamaktadır. Kibir ve kendini beğenme gibi duygulara kapılıp güç zehirlenmesi yaşayabilmektedir. Yunus'un da vurguladığı gibi böyle bir şahıs, bütün bu hallerini Allah'ın bildiği halde ifşa etmemesini büyük bir nimet olarak düşünüp, kusurlarını düzeltmeye çalışmalıdır.

Tasavvufta ilim amel bütünlüğü, özün söz ile uyumlu olması önemsenir. Çünkü derviş, sözü ile eylemi arasında çelişki olmayan kişidir. Şayet dervişin içinde kin, nefret ve kıskançlık gibi kötü duygular varsa, onun tasavvufî hakikatlerden söz etmesinin bir anlamı yoktur. Bunun bilinciyle hareket eden Yunus Emre, nefsi terbiye etmeden, münafiklık belirtilerini silip aklı ve kalbi selîm hale getirmeden derviş olunamayacağını vurgular. ${ }^{66}$

64 Tatç1, Yunus Emre Dîvânı, 41/1-6; 225/1-9.

65 Tatçı, Yunus Emre Dîvânı, 117/6, 9.

66 Tatç1, Yunus Emre Dîvânı, 347/1-2. 
İçin dişın murdâr iken, aşk neylesin senin ile

Gönlün gözü uyur iken, aşk neylesin senin ile

Aş̧ılara yoldaş olup, sâdıklara yâr olmadın

Ölmezden önden ölmedin, aşk neylesin senin ile

Yunus Emre'nin "Dervişliği sanma hemen, suret düzmek ile olur"67 sözü, dervişliğin giyim kuşamla ve dille güzel şeyler söyleyip menkıbeler anlatmakla olmayacağını göstermektedir. Asıl dervişlik; dürüstlük, samimiyet, fedakârlık ve cömertlik gibi ahlâkî erdemlerin yaşanmasıdır. Davranışı Peygamber'in sünnetine uygun olmayan ve onun şahsında somutlaşan ahlâkî değerlere önem vermeyen kişinin sıfatı derviştir ama gerçek dervişlikten nasibi yoktur.

Tasavvufun temel kavramlarından zühd, dünya malına değer vermemek ve ona karşı mesafeli durmaktır. Dolayısıyla dervişin dünyaya gönlünde yer vermemesi gerekir. Hem dünya hem Allah sevgisi dervişlikte birlikte yürümez. Dünyanın malı, mülkü ve süsü peşinde koşarken Allah'ın tahtı olan gönlü imar etmemek olmaz. Rızkını kazanmak için çalışmanın tasavvuf açısından bir engel teşkil etmediği bilinen bir gerçektir. Ancak kalbi dünya sevgisiyle doldurup, hırsla mal mülk yığacağım derken tasavvufun özünden uzaklaşılmaktadır. Böyle bir duruma düşmemek için zühd ve takvâ, kanaat ve rıza gibi erdemleri özümsemek gerekir.

Yunus Emre tasavvufun şahsiyet eğitiminin, zorlu ve çetin bir süreç olduğunu belirterek bu yolda tembelliğe ve kendini diğer insanlardan üstün görmeye yer olmadığını vurgulamıştır. Birçok sûfî gibi Anadolu' da mirasını devam ettirdiği Hoca Ahmed Yesevî de Dîvân-ı Hikmet'te bunlara dikkat çekmiştir. ${ }^{68}$ Dolayısıyla şeriat kurallarına uymadan, fakirliği meslek edinmeden, hakaretlere kulağı tıkamadan, geceleri gözyaşı döküp Allah'a yalvarmadan tarikatta mesafe alınmaz, derviş olunmaz. Kendini hiçbir zaman halktan ayrı ve üstün görmeyen Yunus, sosyal hayatta insanlara bir şey söylerken kendini de onlardan biri gibi değerlendirmenin, halk üzerinde etkili bir yöntem olduğunun farkındadır. Bu yüzden özeleştiri yaparak, insanları incitmeden, ahlâkî değerleri onlara kazandırmaya çalışmıştır.

\section{Sonuç}

Yunus Emre Anadolu Selçuklu Devleti'nin yık1lış, Osmanlı Devleti'nin kuruluş aşamasında yaşamıştır. Tasavvuf öğretisi, sevgi ve hoşgörü merkezli olan Yunus Emre, kargaşa döneminde umudunu yitiren insanlara sevmeyi, müsamahayı ve affetmeyi öğretmiş, güzel ahlâkı yaşanır kılmayı gaye edinmiştir. Seyahat eden

67 Tatç1, Yunus Emre Dîvânı, 347/5-6.

68 Hoca Ahmed Yesevî, Divan-ı Hikmet, hazırlayan: Hayati Bice, Ankara 1998, no: 12/4-10, no: $76 / 1$. 
bir derviş kimliğiyle bu ülküsünü gerçekleştirmeye çalışan Yunus, Anadolu insanı tarafından çok sevilmiş ve onunla manevî yakınlık kurmak düşüncesiyle birçok yerde makam kabirler oluşturulmuştur.

Evrensel ahlâkî değerlerin yaşatılmasına büyük değer veren Yunus Emre, dervişliğin kolay elde edilmediğini, derviş olmak için uzun ve zorlu bir süreç gerektiğini belirtir. Tasavvuf literatüründe bu yolculuk için seyr-i sülûk ifadesi kullanılır. Nefsini tezkiye edip, kalbini arındıran ve böylece tasavvufun şahsiyet eğitimini başarı ile tamamlayan kişiye sûfî ya da derviş denir. Gözü açık, gönlü temiz, kulağı Allah ve peygamber sözüne âşı olan derviş, her gün aynanın karşısına geçip nefis muhâsebesi yaparak ölüme hazırlıklı olur. Bir çeşit nefsi terbiye yöntemi olan dervişlik, gönülden pası silip yeni bir benlik inşa etme sürecidir. Dolayısıyla dervişlik, dürüstlük ve samimiyet, sevgi ve hoşgörü, tevazu ve yardımseverlik, iyilik ve cömertlik gibi ahlâkî erdemleri içselleştirip topluma davranışlarıyla örnek olmaktır. Dervişlik, tebessüm ederek gönül almak, selamlaşarak güven vermek, hiçbir canı incitmemektir. Kusurları görmezden gelmek ve af yolunu seçip hakaretleri müsamaha ile karşılayabilmek, kötülüğe karşı iyilik yapmak ve incitenden incinmemek de dervişliğin bir gereğidir. Yunus'un "bir eskice verip gönle girmek" ifadesinde de görüldüğü gibi dervişlik, kılık kıyafete bürünmek değil, yarım elma ile ya da bir kalemle gönül almaktır. Âşıkpaşazâde’nin “Gâziyân-1 Rûm" olarak isimlendirdiği ${ }^{6}{ }^{9}$ alperenler gibi, din, vatan ve millet uğruna canı feda etmektir. Kısaca dervişlik; doğruluktan ve dürüstlükten taviz vermeden iyi bir insan olarak yaşamak ve çevresindekilere erdemli davranışlarıyla örnek olmaktır.

Tarihi bir şahsiyet olan Yunus Emre'nin sevgi ve hoşgörüye dayalı irade terbiyesi yönteminden günümüzde faydalanmak mümkündür. Şiirleri ilahî ve türkü formunda bestelenen Yunus Emre'nin şahsiyet eğitimi ile ilgili görüşleri eğitimcilere yol gösterebilir. Eğitim ve öğretim kurumlarımızda dürüstlük, iyilik yapmak, fedakârlık, iffetli olmak, beden, kalp ve çevre temizliğine önem vermek gibi erdemler yeni nesillere kazandırılabilir. Böylece onun ilhamını Kur'ân ve Sünnet’ten alan “sevelim sevilelim dünya kimseye kalmaz" sözü, canlılığını korumuş olur.

Hakem Değerlendirmesi: Dış bağımsız.

Çıkar Çatışması: Yazar çıkar çatışması bildirmemiştir.

Finansal Destek: Yazar bu çalışma için finansal destek almadığını beyan etmiştir.

Peer-review: Externally peer-reviewed.

Conflict of Interest: The author has no conflict of interest to declare.

Grant Support: The author declared that this study has received no grant support.

69 Âş1kpaşazâde, Tevârîh-i Âl-i Osman, Matbaa-i Âmire, İstanbul 1332h., s. 204-205. 


\section{Kaynakça/References}

Ahmed b. Hanbel, Müsned, Çağrı Yayınları, İstanbul 1992.

Attâr, Ferideddin, Mantıku't-Tayr, çeviren: Abdülbâkî Gölpınarlı, Milli Eğitim Bakanlığı Yayınları, İstanbul 1990.

Ay, Resul, Anadolu'da Derviş ve Toplum 13-15. Yüzylllar, Kitapyayınevi, İstanbul 2008.

Âşık Paşa, Garib-Nâme, hazırlayan: Kemal Yavuz, TDK Yayınları, İstanbul 2000.

Âşıkpaşazâde, Tevârîh-i Âl-i Osman, Matbaa-i Âmire, İstanbul 1332h.

Buharî, Sahih, Çağrı Yayınları, İstanbul 1992.

Can, Şefik, Hz. Mevlânâ'nın Rubâileri, Kültür Bakanlığı Yayınları, Ankara 2001.

Gazzâlî, Ebû Hâmid, İhyâu Ulûmiddin, Dâru İbn Hazm, Beyrut 2005.

Gölpınarlı, Abdülbâkî, Vilâyet-Nâme, Menâkıb-ı Hünkâr Hacı Bektaş-ı Velî, İnkılap Kitabevi, İstanbul 1990.

Gölpınarlı, Abdülbâkî, Yunus Emre ve Tasavvuf, İnkılap Kitabevi, 2. Bask1 İstanbul 1992.

Hücvirî, Keş̧ü'l-Mahcûb, (Hakikat Bilgisi), hazırlayan: Süleyman Uludağ, Dergâh Yayınları, İstanbul 1982.

İbnü's-Serrâc, Muhammed b. Ali, Tuffâhu 'l-Ervâh ve Miftâhu'l-İrbâh, hazırlayanlar: Nejdet GürkanMehmet Necmettin Bardakçı-Mehmet Saffet Sarıkaya, Kitapyayınevi, İstanbul 2015.

Kaplan, Mehmet, “Telvin”, Türk Edebiyatı, say1: 193, İstanbul 1989, s. 4-6.

Kara, Seyfullah, Anadolu Selçuklularında Din ve Din̂̂ Kurumlar, Atatürk Üniversitesi Sosyal Bilimler Enstitüsü, Yayımlanmamış Doktora Tezi, Erzurum 2002.

Kâzerûnî, Hacı Hüsâm İbrahim b. Muhammed, Şifâü'l-Eskâm fî Sîreti Gavsı'l-Enâm Ahmed er-Rifâ̂ Menkıbeleri, çeviren: Nurettin Bayburtlugil-Ncdet Tosun, Vefa Yayınları, İstanbul 2008.

Kelâbâzî, Ebû Bekir Muhammed b. İshak el-Buhari, et-Ta'arruf li Mezhebi Ehli 't-Tasavvuf, neşr: Arthur John Arbery, Mektebetü'l-Hanc1, 2. Bask1 Kahire 1994.

Müslim, Sahih, Çağrı Yayınları, İstanbul 1992.

Kemikli, Bilal, Sunu'llah Gaybî Divanı, Milli Eğitim Bakanlığı Yayınları, İstanbul 2000.

Köprülü, M. Fuad, Türk Edebiyatında İlk Mutasavvıflar, Diyanet İşleri Başkanlığı Yayınları, 4. Bask1 Ankara 1981.

Kuşeyrî, Abdülkerim, Kuşeyrî Risâlesi, hazırlayan: Süleyman Uludağ, Dergâh Yayınları, 3. Bask1 İstanbul 1991.

Ocak, Ahmet Yaşar, Babaîler İsyanı, Dergâh Yayınları, 2. Baskı İstanbul 1996.

Ocak, Ahmet Yaşar, "Barak Baba”, Diyanet İslâm Ansiklopedisi, c. V, s. 61-62, İstanbul 1992.

Rûmî, Mevlâna Celâleddin, Mesnevî, çeviren: Derya Örs-Hicabi Kırlangıç, Türkiye Yazma Eserler Kurumu Yayınları, İstanbul 2015.

Serrâc, Ebû Nasr, el-Luma', tahkik: Abdülhalim Mahmûd-Tâhâ Abdülbâkî Sürûr, Kahire 1960.

Şahin, Haşim, "Yunus Emre'nin Şeyhi Tapduk Emre", Yunus Emre, editör: A. Yaşar Ocak, Kültür ve Turizm Bakanlığı Yayınları, Ankara 2015, s. 199-227.

Tatçı, Mustafa, Yunus Emre Dîvânı, H Yayınları, İstanbul 2020.

Vâsitî, Takiyyüddîn Abdurrahman Ebû'l-Ferec ibn Abdi'l-Muhsin, Tiryâku'l-Muhibbîn fî Tabakâti Hırkati'l-Meşâyihi'l-Ârifin, Matbaatü'l-Behiyye, Kahire 1305h.

Yasa, Metin, "Yunus Emre'de Ben Bilinci: Ben Ötesi Psikolojisi Açısından Bir Değerlendirme", Uluslararası Yunus Emre Seтроzуити Bildirileri, İstanbul 2010, s. 72-76.

Yesevî, Hoca Ahmed, Divan-ı Hikmet, hazırlayan: Hayati Bice, Ankara 1998. 
